\title{
Acceptability of Environmental Policies in the Czech Republic: A Comparison with Willingness to Make Economic Sacrifices
}

\author{
Eva Kyselá
}

\begin{abstract}
This study aims to identify factors which influence the acceptability of environmental policies and to examine policy acceptability in comparison to willingness to make economic sacrifices for environmental protection. Data for the Czech Republic from the International Social Survey Programme Environment module from 2010 are analysed using regression analysis. Environmental concern, preferences for the role of the state in environmental protection, and trust toward politicians have been identified as factors influencing policy acceptability. Although the declared acceptability of environmental policies in the Czech Republic is high, willingness to make economic sacrifices is low and is not related to acceptability. The results support the conclusion that the two indicators are measuring different concepts.
\end{abstract}

KEYWORDS Environmental policy, policy acceptability, environmental concern, environmental protection, trust, Czech Republic

\section{Introduction}

The search for the optimal policy mix continues in the ongoing debate on the European emission reductions goals to be set for 2030 (and later for 2050). Nation-states are expected to have more freedom to choose the national goals and policy mix in the period from 2020 to 2030 (European Commission 2014). If so, the nationally elected representatives will have the main decisive power. Policy feasibility and acceptability thus become a major issues. Policy makers might be reluctant to advance unpopular policies. The lack of public acceptance of proposed policies, or even opposition towards them, could prevent their implementation or lead to implementation of more popular but otherwise inefficient policies (e.g. some sort of information campaign). Policy makers should therefore be informed about potential barriers which need to be overcome, including public perception, and ways to improve policy acceptability.

Sociálni studia. Department of Sociology FSS MU, 3/2015. S. 179-198. ISSN 1214-813X. 
The issue of policy acceptability or acceptance thus receives increasing attention and the amount of research is fast growing. However, the concept of policy acceptability is quite new and not yet well defined ${ }^{1}$ (Zvěřinová, Ščasný and Kyselá 2014). This study attempts to contribute to existing research, reviewed briefly below, by examining some factors previously identified having an influence on acceptability and examining the concept in comparison to a related measure of willingness to make economic sacrifices for environmental protection.

According to Stern's (2000) widely used classification of environmentally significant behaviour, acceptance (or acceptability) of and support for environmental policies are cases of non-activist behaviour in the public sphere, as opposed to environmental activism (e.g. active involvement in an environmental organization) and private-sphere environmentalism (e.g. consumer behaviour, use of appliances etc.). Willingness to pay higher taxes can be cited as another example of such non-activist behaviour. This latter example has been also used to measure environmental policy acceptability (e.g. Gelissen 2007; Stern et al. 1999) or as an indicator of the degree of public support (Jin and Shriar 2013). As a consequence, every policy will affect citizens by either higher taxes or prices, which often lead to a lower standard of living, as citizens have lower incomes or higher expenses. Therefore, accepting a policy should be linked to the willingness to finance it. Both policy acceptability and willingness to sacrifice express some intent (i.e. intent to accept or support a policy and intent to accept higher prices, or the contrary). But while policy acceptability as defined here (see below) is mainly an attitudinal concept and is more disconnected from everyday life, willingness to sacrifice can reflect particular effects of the possible policies on said everyday life. Therefore, we may assume there are differences in the factors influencing the two.

The goals of this study are to identify the factors which influence policy acceptability and to compare the structure of influential factors of the two measuers. The study compares policy acceptability and willingness to sacrifice indicators in order to see whether they are indeed measuring the same thing or are influenced by the same factors. This could inform the practice of measuring and analysing policy acceptability, particularly when using datasets such as the ISSP (International Social Survey Programme) or the European Values Survey, where willingness to pay higher taxes and prices and to accept lower living standards for environmental protection are common variables utilized in cross-national and time-series analyses.

In general, several groups of determinants of environmentally significant behaviour have been identified, especially in social-psychological research. Steg and Vlek (2009), distinguish three groups of determinants ${ }^{2}$. First, motivational factors, such as weighing costs and

The term acceptability is often used interchangeably with such terms as support or acceptance in empirical research, although the argument has been made that these terms are not synonyms (Batel, Devine-Wright and Tangeland 2013; Dreyer and Walker 2013; Schade and Schlag 2003). While both acceptability and acceptance are reportedly based more on attitudes, and are therefore passive, support comprises a behavioural component as well (Batel et al. 2013; Schade and Schlag 2003). In this study, the term acceptability is used in line with previous conclusions, i.e. meaning an attitude towards a proposed policy before it is implemented.

2 Habit and habitual behaviour is the third group, not reviewed here for the sake of brevity. 
benefits, moral and normative concerns and obligations, environmental concern, and affect, are the domain of psychological and social-psychological research. Social-psychological theoretical models of (not only) environmentally significant behaviour represent the dominant approach in research of motivational factors. This research has already identified several factors influencing acceptability (see Harring and Jagers 2013; Steg, Dreijerink and Abrahamse 2005; Schade and Schlag 2000 for application of dominant theoretical models): general ${ }^{3}$ (Dietz, Dan and Shwom 2007; Leiserowitz 2006; Poortinga et al. 2012; Steg et al. 2005) and environmental values (Dietz et al. 2007; Eriksson, Garvill and Nordlund 2006; Steg et al. 2005), personal (Cools et al. 2011; Harring and Jagers 2013) and social norms (Schade and Schlag 2003), and trust (Dietz et al. 2007; Harring and Jagers 2013; Kallbekken and Sælen 2011). There is also some evidence for the role of knowledge (McCright 2008; Zahran et al. 2006).

Second, contextual factors are another group of determinants as argued by Steg and Vlek (2009). Social and environmental context, policy context, political system and dispositions are important. Harring (2013), for example, explores the effects of corruption and political trust on acceptability of policies. Several more specific and more contextual-based factors have proven influential in the research of policy acceptability (for reviews see Alló and Loureiro 2014; Jaensirisak, Wardman and May 2005; Pridmore and Miola 2011; Steg and Schuitema 2007 for transport measures; Steg, Dreijerink and Abrahamse 2006), namely policy specific beliefs. People tend to prefer measures that do not constrain their possibilities and freedom. In consequence, pull measures, based on incentives for environmentally friendly behaviour, rather than push measures penalizing negative behaviour, are preferred (Attari et al. 2009; Fujii et al. 2004; de Groot and Schuitema 2012). A positive attitude towards the proposed policy also positively relates to perceived effectiveness ${ }^{4}$ (Bostrom et al. 2012; Dreyer and Walker 2013; Fürst and Dieplinger 2013; Kim et al. 2013) and perceived fairness (distribution of costs or benefits; Dreyer and Walker 2013; Jagers, LöFgren and Stripple 2010; Kim et al. 2013; Schmöcker, Pettersson and Fujii 2012; Schuitema, Steg and Kruining 2011). People also consider the specific characteristics, framing, and label (Lockwood 2011; Löfgren and Nordblom 2009) of the instrument at hand (e.g. how the policy is named, how it is formulated, and how it is presented to the public). They need to understand the policy instrument and its logic (e.g. maintaining the overall tax revenue in ecological taxation scheme); otherwise, they are rather suspicious about the mechanisms (Dresner, Dunne et al. 2006; Dresner, Jackson and Gilbert 2006). Perceived environmental effectiveness of a policy also increases with environmental earmarking (Sælen and Kallbekken 2011).

Trust, either general social or more specific political, seems to be a major determinant of policy acceptability or support, although it is not included in the major social-psychological models. The results of the study of Harring and Jagers (2013) give mixed evidence for the

3 General values include worldviews and basic value orientations, for example Inglehart's concept of postmaterialist and materialist values (Inglehart 1995), or egoistic, altruistic and biospheric values inlcuded in the Value-Belief-Norm theory (Stern 2000).

4 Although the evaluation of an instrument's effectiveness may be only a rationalization of an attitude based on other, less rational, factors, such as the general dislike of taxes. 
influence of general social trust (only significant at a 90\% level), but the effect may be mediated by other variables such as trust toward institutions and perceived fairness or effectiveness of policy instruments (Kim et al. 2013; Schmöcker et al. 2012). More research is needed in this regard. On the other hand, several studies of environmental policy acceptability have provided empirical evidence for the positive effect of trust towards politicians (Hammar and Jagers 2006; Harring and Jagers 2013; Jagers et al. 2010; Lubell and Vedlitz 2006) or the relevant institutions (Adaman et al. 2011). Kallbekken and Sælen (2011) conclude that trust in governmental use of the revenues in general is one of the most important predictors of policy acceptability and, in the study of Harring and Jagers (2013), trust toward politicians has a statistically significant and independent effect even if other variables, such as ideology or selfinterest, are included in the model.

Several studies have analysed the ISSP Environment dataset used in this paper. Most frequently, the research has focused on environmental attitudes or environmental concern in a comparative way both internationally and over time (Franzen and Meyer 2010; Franzen and Vogl 2013; Hadler and Wohlkönig 2012; 2012a, 2012b; Olofsson and Ohman 2006; for analysis of the Czech data see Řeháková 2001; Soukup 2001; Soukup and Jandová 2001). We review some theoretical approaches that try to explain individual as well as cross-national differences in environmental attitudes. Particularly, we discuss Inglehart's theory of postmaterialism, Dunlap and Mertig's globalization explanation, and the prosperity hypothesis. Second, we test these hypotheses by applying multilevel analysis to the International Social Survey Programme (ISSP). Some authors analysed the predictors of willingness to sacrifice (Haller and Hadler 2008), i.e. willingness to make economic/financial sacrifices (Gelissen 2007; Harring 2013) or willingness to pay (Ivanova and Tranter 2008). Inglehart's (1977) postmaterialist value orientation, education, environmental concern or risk perception (Gelissen 2007; Ivanova and Tranter 2008), income (Gelissen 2007; Haller and Hadler 2008), and age (Gelissen 2007) have been identified as influencing willingness to make economic sacrifices. However, no study has analysed actual policy acceptability since no such question is included in the international module of the ISSP; it is however present in the Czech version. Therefore, only data for the Czech Republic are analysed with special regard to the national policy context.

\section{The context of the Czech environmental policy}

The policy options presented in the 2010 questionnaire and analysed in this study (i.e. feed-in tariffs for renewable energy, ecological taxation of polluting businesses, and subsidies for residential heat insulation) have already been implemented in some form in the Czech Republic. Feed-in-tariffs for electricity from renewable energy sources were first implemented in 2000 and subsidies for home insulation are integrated within the Green Savings programme. There is no direct taxation of high-polluting businesses, although electricity and fuel taxes and airpollution fees for non-carbon dioxide greenhouse gases are in effect (for a general overview of instruments see Máca 2013).

The Green Savings programme incorporates not only subsidies for thermal insulation of residential (and later public) buildings, but also financial support for other measures - passive 
energy standards for new construction and the switch to RES for heating. The programme was started in 2009, a year before the data collection. The awareness of this programme may still have been low at the time, although it received a large portion of attention by media and political elites. The feed-in-tariffs for RES electricity received attention from 2009 until 2012 when a substantial change in legislation finally followed the controversy which arose due to too slow between-year decreases in guaranteed prices and falling prices of the technology for solar power plants. This highly profitable situation has led to an increase in the share of renewables from $4.9 \%$ in 2006 to $8.3 \%$ in 2010 (10.3\% in 2011) and to a considerable increase in electricity prices (the RES premium increased from $34 \mathrm{CZK} / \mathrm{MWh}$ in 2006 to 582 $\mathrm{CZK} / \mathrm{MWh}$ in 2010; data from the Czech Energy Regulatory Office). Moreover, many cases of corruption and unfair trading were uncovered (distrust toward politicians and governmental bodies could be expected on this account). The Czech Republic was also quite successful in biofuels production until 2009 when the steady support weakened in reaction to the biofuels controversy. Scepticism toward any environmental policy could be expected due to these rather controversial cases, negatively influencing support for some or all measures. The overall popularity of subsidies, and the general preference for the regulation of businesses ${ }^{5}$ could probably increase the acceptability of this type of instrument (i.e. Green Saving programme), while negative experience with support for RES could lead to an overall negative attitude.

\section{Methods}

ISSP data set

Data from the International Social Survey Programme 2010 Environment module for the Czech Republic are analysed. The collection of data took place in June 2010 by face-to-face pen-and-paper interviews. A representative sample of 1422 citizens aged 18 years or older is based on a three-level stratified probability sampling procedure. ${ }^{6}$ The response rate was $64.9 \%$ (including the boost data for young repondents, excluded from analyses in this study). The data were weighted for correction of the sampling design and unit non-response.

The variables entering the analyses were checked for missing data. No pattern was discovered and the data appear to be missing at random (MAR). ${ }^{7}$ The size of the sample analysed in regression is 988 cases if cases with missing data are deleted listwise. The group of

5 Czech respondents in the ISSP 2010 Environment survey preferred state regulations more often if the subject of the regulation were businesses ( $83 \%$ of all respondents, $\mathrm{N}=1427)$ compared to markedly lower preference for regulations concerning citizens ( $60 \%$ of all respondents, $\mathrm{N}=1427$ ).

6 Sampling levels were: stratified probability sampling of residential areas, stratified sampling of households, Kish table based selection of household member.

7 Missing at random (MAR) refences here to Rubin's commonly used denotation of patterns of missingness (Allison 2002; Graham 2009; Leite and Beretvas 2010; Roth 1994; Schafer and Graham 2002; Sinharay, Stern and Russell 2001). Compared to missing completely at random (MCAR) which is what we usually intuitively understand as random, i. e. missing data are not related to either observed nor unobserved cases, MAR means that missing data are related to observed values, but we assume that they are not related to unobserved values. The assumption of MAR cannot be proved since missing data are not available to analyse. 
cases which are deleted in a complete-case analysis is statistically significantly different from the group left in the analyses in regard to age (Mann-Whitney $U$ test, sig. $<0.001$ for both groups given the dependent variable) and political orientation (chi-quare test sig. $<0.001$ for both groups given the dependent variable). This violates the assumption that data are missing completely at random. Moreover, the presence of missing data in several items of independent variables is related to some dependent variables (e.g. answers for willingness to sacrifice items are statistically significantly - chi-square test sig $<0.001$ - different for those not answering to what degree they consider global warming dangerous). Proceeding with complete-case analyses could in this case lead to biased estimates (Allison 2002). Therefore, missing data in scale items (not socio-demographics such as education) were imputed using the multiple imputation method. ${ }^{8}$ All analyses were conducted on both imputed and original data. The results are uniform - the estimates in both analyses differ only slightly. Therefore, results for complete-case analysis are presented throughout the paper. The key demographic and socio-economic properties of the representative sample are presented in Table 1.

Table 1: Sample characteristics (original weighted data; N=1427)

\begin{tabular}{|c|c|c|c|c|c|}
\hline & \multirow[t]{2}{*}{ count } & \multirow[t]{2}{*}{$\%$} & \multicolumn{2}{|r|}{ count } & $\%$ \\
\hline Age & & & \multicolumn{2}{|l|}{ Education } & \\
\hline $18-29$ & 283 & 19.8 & primary & 725 & 50.8 \\
\hline $30-44$ & 408 & 28.6 & secondary & 508 & 35.6 \\
\hline $45-59$ & 353 & 24.8 & tertiary & 194 & 13.6 \\
\hline 60 and over & 383 & 26.8 & \multicolumn{3}{|c|}{ Monthly net household income $(\mathrm{N}=891)^{a}$} \\
\hline Gender & & & up to $15000 \mathrm{CZK}$ & 298 & 20.9 \\
\hline female & 693 & 48.6 & $15001-30000$ & 365 & 25.6 \\
\hline male & 734 & 51.4 & $30001-45000$ & 163 & 11.4 \\
\hline \multicolumn{2}{|c|}{ Subjective status $(\mathrm{N}=1375)$} & (S.E.) & 45000 and more & 64 & 4.6 \\
\hline Mean & 4.73 & $(0.046)$ & \multicolumn{2}{|c|}{ Political orientation ( $N=1173)$} & (S.E.) \\
\hline sd & 1.713 & Min $=0$ & Mean & 5.06 & (0.07) \\
\hline + Don't know & 32 & $M a x=10$ & $\mathrm{sd}$ & 2.412 & Min $=0$ \\
\hline \multirow[t]{2}{*}{ + No answer } & 20 & & + Don't know/Refuse & 190 & Max $=10$ \\
\hline & & & + No answer & 63 & \\
\hline
\end{tabular}

8 Data were imputed with 20 imputations by 50 iterations utilizing Fully Conditional Specification method provided by Multiple imputation tool build in the SPSS Statistics v19 software. Predictive Mean Matching was used for scale variables. Likert-type scales were treated as scale variables in the imputation process, since the method is robust towards violations of normality and continuity assumptions (Leite and Beretvas 2010). One case was deleted from the dataset since the respondent did not answer all subquestions of the key variables. The imputation model included all variables used in the analyses and other related variables present in the questionnaire. 


\section{Variables}

Given the fact that the ISSP Environment module does not contain any constructs of existing social-psychological models, no such model can be tested in this study. However, the role of several social-psychological constructs is examined ad hoc; particularly general social and more specific political trust, preferences regarding the role of the state in environmental protection, environmental concern and postmarialist value orientation (see above). The means of constructed scales and wordings of questions and scale items are presented in Table 3 in the Appendix.

The policy acceptability scale was constructed as an average score on three 5-point Likert items ${ }^{9}$ assessing the acceptability for three different policy instruments, namely an ecological tax for polluting businesses, support for renewable energy sources (RES) by feed-in tariffs, and improving energy efficiency through financial support for residential home thermal insulation (see for example Bostrom et al. 2012; Schmöcker et al. 2012; Zahran et al. 2006 for examples of similar measurement of policy acceptability). The Czech equivalent of the term support was used in the question wording of the dependent variable used in this study. Moreover, the general instruments named in the questionnaire are already implemented or were implemented at the time of data collection. However the concept measured by the question is closer to acceptability as it is rather attitudinal and the question is hypothetical without regard to the actual state of the policy or respondents' knowledge of it. In consequence, the term acceptability refers to the dependent variable despite the translation issue.

Second, a willingness to sacrifice scale was constructed as an average of three 5-point Likert item scores on willingness to pay higher prices, willingness to pay higher taxes and willingness to accept a lower standard of living.

Two items of general social trust (Spearman-Brown statistic for consistency of two-item scales is 0.815 indicating sufficient consistency) and one item of political trust were used for the key explanatory variables. Although there are two items on political trust in the questionnaire, their internal consistency was low (Spearman-Brown statistic 0.584) and hence only one was chosen for regression analyses to avoid multicollinearity problems, namely level of respondent's agreement with statement that politicians are motivated solely by self-interest.

Several items were inspected regarding the concept of environmental values or worldview, ${ }^{10}$ but no possible set yielded a satisfyingly consistent scale or sufficiently high inter-item correlations. ${ }^{11}$ However, two other related scales were constructed: environmental concern (perception of environmental risks) and perception of one's own capacity to act

9 The item scale ranged from 1 (definitely support) to 5 (definitely not support). It is worth noting that such a scale is intrinsically one-dimensional - there is no opposition in the phrasing of the item scale, only lack of support. The scales were inversely recoded for the sake of interpretation lucidity. Unfortunately, the complete New Environmental Paradigm scale widely used to measure environmental values was not included in the questionnaire. The research on policy acceptability however suggests it has predictive power (Attari et al. 2009; Bord, O’Connor and Fisher 2000; Shwom et al. 2010; Steg et al. 2011).

11 Criteria for the internal consistency of scale were Cronbach's alpha equal or higher than 0.7 and inter-item correlations equal or higher than 0.5 . 
(self-efficacy or locus of control). Five items out of seven in total were used for the environmental concern scale (Cronbach's alpha 0.781). The two excluded items concerned GMO and nuclear energy, two topics which are rather controversial in the Czech Republic (GMO is not yet well known among the public, thus there is a high rate of missing data in this question, and nuclear energy is often presented as a "green" energy solution, hence not always regarded as an environmental threat). Another five items from seven in total served in the construction of the self-efficacy scale (Cronbach's alpha 0.723). The ISSP includes two variables to measure postmaterialist value orientation as conceptualized by Inglehart (1997). The

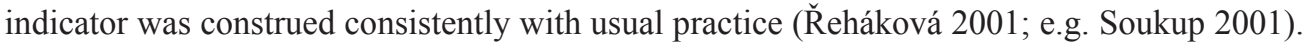
Respondents were given four options when answering the questions what is the most and second most important priority for the Czech Republic: maintaining order in the nation, giving people more say in important government decisions, fighting rising prices, or protecting freedom of speech. The first and third options are regarded as materialist priorities, while the second and fourth as postmaterialist ones. Individuals were coded as materialists if they chose any of the materialist priorities in both questions or as postmaterialist if they chose opposite in both questions. If a combination of postmarialist and materialist priority in any order was chosen, the respondent was coded as "mixed".

Respondents' preferences regarding the role of the state in the protection of the environment were assessed in two binary-choice questions on whether the state should let citizens decide how to protect the environment or instead pass some laws to ensure protection. The same two options were posed for businesses and their behaviour. Further, right-left political orientation was measured on 11-point scale.

The standard socio-demographic variables such as gender, age, and education were included in the models. Income, with a large proportion of missing data with a high probability of missing data not being at random (individuals with higher or lower income may opt not to report their level), was substituted by self-assessed social class membership measured on 11-point scale. It can reasonably be assumed that the perception of one's status and wealth, as a proxy for subjective ability to pay, is at least equally important for the willingness to sacrifice some amount of money or comfort as the actual income. All question wordings and means are presented in the Appendix.

\section{Analyses}

In the first step, a model, developed in line with the literature review results, social-psychological theories, possibilities given by the ISSP questionnaire, and correlation analysis (see Table 4 in Appendix) is tested by OLS regression analysis. Socio-demographic characteristics of the respondent (gender, age, subjective assessment of social status, education) and socialpsychological constructs as introduced earlier (environmental concern, self-efficacy, general post/materialist values, general trust and trust towards politicians, and preferences for the role of the state) are included as independent variables. The model is used for analysis of policy acceptability and willingness to sacrifice.

No independent variable posed a collinearity problem in the models (based on variance inflation factor - VIF, and values of tolerance with criteria set to not higher than 3 and not 
lower than 0.3 respectively (Field 2013: 196). However, the dependent variables are severly skewed, as may be clearly seen in Figure 1. This contributes to the violation of the assumption of homoscedasticity of residuals in both models. Unfortunately, no transformation of the dependent variables could amend the problem. Therefore ordinal regression for policy acceptability and multinomial logistic regression for willingness to make economic sacrifices (the ordinal model of willingness to sacrifice failed the test of parallel lines) were computed to check the validity of the results of the OLS regression. Both models yielded the same results, i.e. the same factors were flaged as statistically significant as in the linear regression, hence the OLS estimates are presented in the text for the sake of readability of interpretation. The level of alpha $=0.05$ has been chosen for interpretation of regression results. SPSS Statistics version 17 was used for the analyses.

Figure 1: Histogram of policy acceptability and willingness to sacrifice - general indicators distributions (original data; $\mathrm{N}=1427$ )

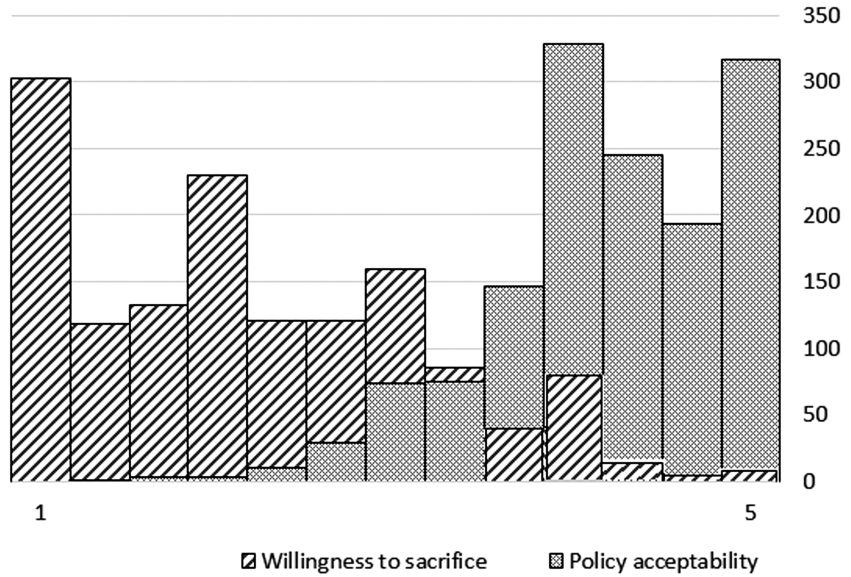

\section{Results}

Respondents generally found the three presented policy instruments very acceptable. As expected given the negative experience mentioned earlier, the acceptability of electricity generation from RES is considerably lower, but still surprisingly high (see Figure 2). On the other hand, respondents also expressed a strong reluctance to accept the direct or indirect effects of policies. However, the phrasing of the questions may be the reason for the strong opposition, since they asked about willingness to pay much higher prices or taxes.

Interestingly, policy acceptability and willingness to sacrifice indicators are not correlated (Kendall's Tau-b for non-linear relationships see Table 4 in Appendix). The item sets for these variables were not connected in any way in the questionnaire and the phrasing of the questions did not imply any relation either. Although the answers to these two questions could be expected to be related, the opposite is true. We therefore have high acceptability of 
environmental policies on one hand and lack of willingness to accept their costs on the other. The lack of relationship, by itself, implies that the two indicators are not measuring the same thing. This is further supported by the results of factor analysis of all the items comprised in the two indicators - it confirms the two-factor structure very clearly. ${ }^{12}$ The following regression analysis explores whether these two indicators are influenced by different factors and which factors they might be.

Figure 2: Responses to policy acceptability and willingness to sacrifice items (\%; original data; N=1427)

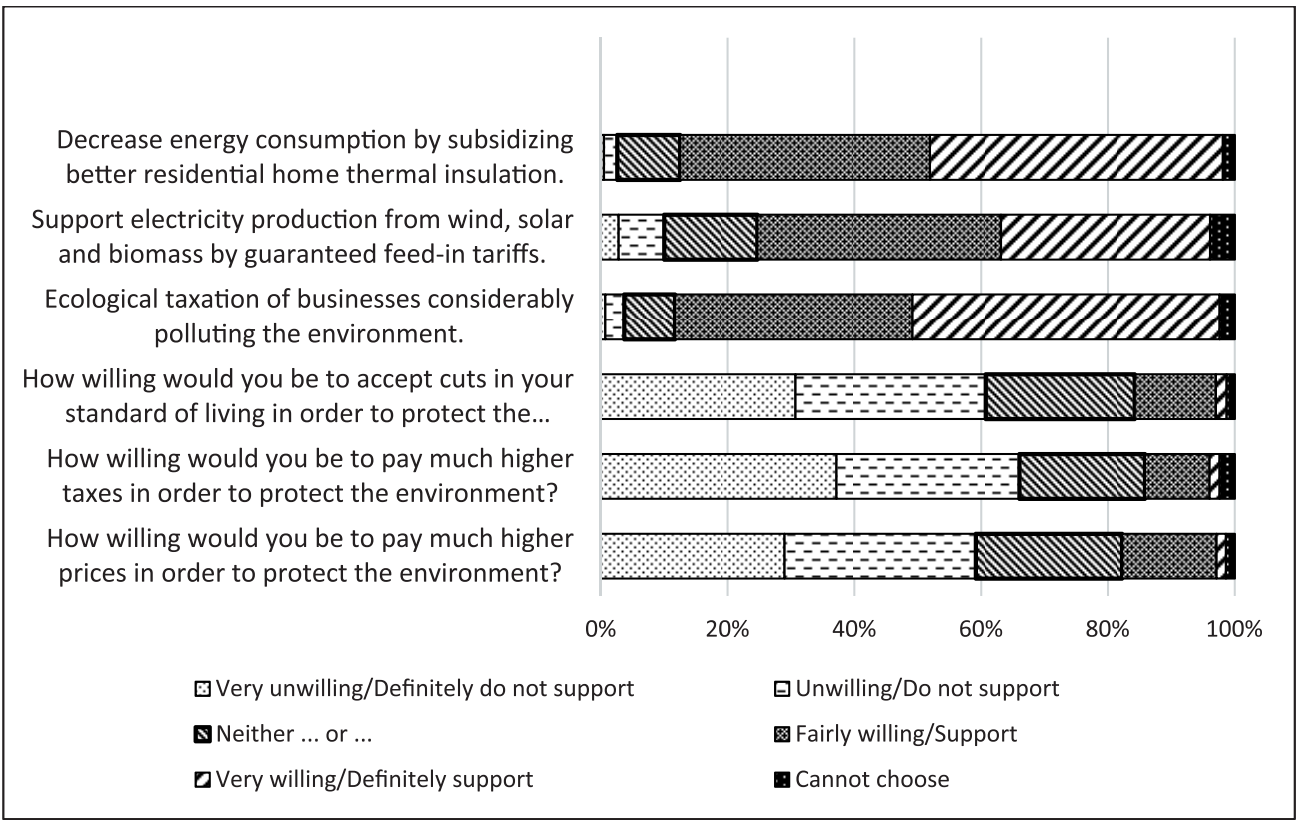

Note: Question To what degree would you support following environmental policy measures?

\section{Policy acceptability}

The results of the regression analyses of the policy acceptability indicator are presented in Table 2. The adjusted $\mathrm{R}^{2}$ is quite low. With the exception of age, no other socio-demographic variable has a statistically significant relationship to policy acceptability. The negative effect of age is not large, however. Still, younger respondents tend to be slightly more in favour of proposed policies.

12 Bartlett's test of sphericity sig. $<0.001$, unrotated solution, factor loadings for factor 1 - willingness to sacrifice - ranging from 0.771 to 0.896 and for factor 2 - policy acceptability - ranging from 0.486 to 0.714 . 
Consistent with previous research on various types of environmentally significant behaviour (see above) environmental concern has a statistically significant positive effect, as expected - those who are more concerned about environmental risks are also more likely to accept environmental policies. Interestingly, general materialist or postmaterialist value orientation has no effect on policy acceptability. Neither has general social trust. Specific trust toward politicians, on the other hand, has a statistically significant effect. Surprisingly, this effect is opposite than expected - those who agree with the statement that politicians are in politics only for what they can get out of it personally are more likely to accept environmental policies compared to the reference middle category (nor agreement or disagreement). Disagreement with the statement does not relate to change in acceptability. It is hard to judge what may be the cause of this unexpected effect, but one suggestion could be that regulation and policies are a kind of insurance or instrument to control the behaviour of others, including the politicians whom we may not trust. The preferences regarding the regulations of environmental protection for citizens and businesses have a positive effect on policy acceptability. Those who prefer state regulations for both citizens and businesses are more likely to accept the policies. This is in accordance with expectations. No other independent variable has a statistically significant effect.

\section{Willingness to sacrifice}

The model for willingness to sacrifice has a relatively higher explanatory power. More factors also have statistically significant coefficients. As expected, subjective social status has a statistically significant influence. No demographic variable does. Besides the statistically significant positive effect of environmental concern, there is a very small, yet statistically significant, effect of postmaterialist value orientation. To be precise, those who are coded as either mixed (i.e. have chosen one materialist and one postmaterialist priority) or as postmaterialist are slightly more likely to be willing to make economic sacrifices than materialists. Furthermore, the preferences regarding the role of the state in environmental protection have no impact, although paying higher prices or taxes implies the existence of some policy.

The self-efficacy variable, reflecting perceived personal barriers to behaving in an environmentally friendly way, has a positive effect on willingness to make economic sacrifices. Those who feel less infringed upon by perceived barriers to act pro-environmentally are more likely to be willing to pay higher taxes or prices or accept a lower standard of living. This supports the idea that policy acceptability is more of an attitudinal construct, while willingness to sacrifice is closer to the conative aspect of environmental attitudes (see for example Franzen and Meyer 2010).

Both general social trust and trust in politicians have a statistically significant effect, but the latter is negligible. The positive effect of general social trust might be surprising, given that it had no statistically significant effect on policy acceptability. This could be related to the stakes vested in the willingness to make economic sacrifices - as they are higher than in the case of simply accepting some policy; trust towards others is more decisive. Harring and Jagers (2013) argue that environmental problems are social dilemmas laden with the freerider problem and moreover, short-term benefits are usually preferred over long-term ones. In 
such a circumstance, trust toward fellow citizens is crucial for one's own action. $41 \%$ of the respondents in the present study agreed that it is not worth acting pro-environmentally unless other people contribute as well. This supports the idea that a more specific assessment of trust toward fellow citizens is needed.

Table 2: Results for regression models (original weighted data; $\mathrm{N}=988$ )

\begin{tabular}{|c|c|c|c|c|c|c|c|c|}
\hline \multirow[b]{3}{*}{ Subjective status } & \multicolumn{4}{|c|}{ Policy acceptability } & \multicolumn{4}{|c|}{ Willingness to sacrifice } \\
\hline & \multirow{2}{*}{$\begin{array}{c}\text { Beta } \\
-0.006\end{array}$} & \multirow{2}{*}{$\begin{array}{c}\text { sig. } \\
0.860\end{array}$} & \multicolumn{2}{|c|}{$\mathrm{Cl}(95 \%)$} & \multirow{2}{*}{$\begin{array}{c}\text { Beta } \\
0.157\end{array}$} & \multirow{2}{*}{$\begin{array}{c}\text { sig. } \\
0.000\end{array}$} & \multicolumn{2}{|c|}{$\mathrm{Cl}(95 \%)$} \\
\hline & & & -0.030 & 0.025 & & & 0.054 & 0.129 \\
\hline Political orientation & -0.007 & 0.834 & -0.021 & 0.017 & 0.087 & 0.006 & 0.010 & 0.062 \\
\hline Age & -0.134 & 0.000 & -0.008 & -0.003 & -0.022 & 0.461 & -0.005 & 0.002 \\
\hline Social trust & -0.040 & 0.191 & -0.070 & 0.014 & 0.115 & 0.000 & 0.058 & 0.172 \\
\hline Enviromental concern & 0.309 & 0.000 & 0.259 & 0.388 & 0.160 & 0.000 & 0.155 & 0.331 \\
\hline Self-efficacy & 0.012 & 0.701 & -0.047 & 0.070 & 0.245 & 0.000 & 0.245 & 0.403 \\
\hline $\begin{array}{l}\text { Politicians self- } \\
\text { interested (agrees) }\end{array}$ & 0.134 & 0.000 & 0.096 & 0.301 & -0.097 & 0.004 & -0.343 & -0.067 \\
\hline $\begin{array}{l}\text { Politicians self- } \\
\text { interested (disagrees) }\end{array}$ & 0.030 & 0.383 & -0.083 & 0.215 & -0.048 & 0.134 & -0.354 & 0.047 \\
\hline Secondary education ${ }^{b}$ & -0.039 & 0.255 & -0.146 & 0.039 & -0.013 & 0.679 & -0.151 & 0.098 \\
\hline Tertiary education ${ }^{b}$ & 0.009 & 0.804 & -0.114 & 0.147 & 0.042 & 0.199 & -0.061 & 0.292 \\
\hline Female $^{c}$ & -0.002 & 0.941 & -0.082 & 0.076 & 0.051 & 0.068 & -0.007 & 0.206 \\
\hline $\begin{array}{l}\text { Mixed preference for } \\
\text { role of the state }\end{array}$ & -0.044 & 0.251 & -0.195 & 0.051 & -0.046 & 0.207 & -0.274 & 0.060 \\
\hline $\begin{array}{l}\text { Preference for state } \\
\text { regulation }^{d}\end{array}$ & 0.125 & 0.002 & 0.066 & 0.279 & 0.019 & 0.605 & -0.107 & 0.183 \\
\hline Mixed value type & -0.009 & 0.766 & -0.098 & 0.072 & 0.086 & 0.004 & 0.055 & 0.285 \\
\hline Postmaterialiste & -0.020 & 0.536 & -0.216 & 0.112 & 0.069 & 0.021 & 0.039 & 0.486 \\
\hline Constant & 3.105 & 0.000 & 2.755 & 3.455 & -0.525 & 0.030 & -0.998 & -0.052 \\
\hline Adjusted $\mathrm{R}^{2}$ & \multicolumn{4}{|c|}{0.164} & \multicolumn{4}{|c|}{0.265} \\
\hline \multicolumn{9}{|c|}{$\begin{array}{l}\text { a reference category neither agree or disagree } \\
\text { b reference category primary education } \\
\text { c reference category male } \\
\text { d reference category preference for individual action } \\
\text { e reference category materialist }\end{array}$} \\
\hline
\end{tabular}

\section{Discussion and conclusions}

The aim of this study was to identify and compare the sets of factors influencing acceptability of environmental policies and willingness to make economic sacrifices (i.e. willingness to pay higher prices or taxes or to accept lower living standards). Both of these indicators have been used to measure policy acceptability in previous studies (see above). Although the regression models have only modest fit, the results clearly indicate the differences in the set of influential factors between them. In this regard, it is necessary to take into consideration the different 
nature of each indicator as measured in the ISSP questionnaire. While policy acceptability is more attitudinal, although the policy instruments have been already implemented, willingness to sacrifice is more a measure of intent. The results support this conceptual difference - the effect of perceived self-efficacy, i.e. the perceived barrier to act, is statistically significant for willingness to sacrifice, but not for acceptability of environmental policies.

The measures also differ in regard to financial costs stated in the questions. This is projected into the relationships with subjective social status. Naturally, variables which imply cost to citizens, as in the willingness to pay much higher prices or taxes questions, are positively affected by higher subjective social status. However, policy acceptability was assessed without any mention of costs of implementing the policy, while willingness to sacrifice is mainly based on financial sacrifices. Yet these two are in fact inherently related. Higher prices of products (principally followed by a decrease in living standard as the household has less money to spend on other goods) are usually an indirect effect of higher taxes imposed on businesses. Higher taxes, on the other hand, are usually a tool for collecting money earmarked to subsidies, such as those for the thermal insulation of residential homes. It seems, though, that respondents are not aware of this connection, as such awareness would presumably lower the acceptability of policies and would at least partially manifest in a relationship between acceptability and willingness to sacrifice - a relationship which is now absent. According to Rhodes and Jaccard (2013), policy acceptance is influenced by the visibility of costs. They show in their case study that the clean electricity regulation policy in British Columbia gained better acceptance by the public because its costs were unseen or invisible to the general public, while the acceptance of carbon tax was lower as people were generally aware of its costs. This is, although indirectly, supported by the results of this study high acceptability of three different policies is in striking opposition to strong reluctance to sacrifice either money or comfort. On the other hand, specification of minor costs can also increase acceptability where the initial level of acceptability is low (or opposition is present). This could be, for example, the case of taxes, which are generally disliked by the public, and the costs people associate with them could be expected to be higher (Lachapelle, Borick and Rabe 2012).

There is no statistical relationship between the indicators of policy acceptability and willingness to sacrifice. This points to the terminological and conceptual disparities of policy support or acceptability definition and measurement. Both measures used in this study can be found in empirical studies as measures of policy acceptability, but as is clearly shown, both yield very different results (including a different set of influential factors). Including money or the actual effects policy would have on a respondent's life may change the course of consideration and the overall outcome of the question. On the other hand, the general willingness to make economic sacrifices lacks any specification of policy or instrument attributes. Policy instruments can be defined on different levels of specificity and with many different characteristics. It seems that measuring acceptability by asking about general environmental policies, or even more problematically about environmental policy in general, will yield results positively biased towards higher levels of acceptability or support. Policy acceptability or support should be measured while respondents are aware of the actual (economical) consequences of the policy at hand (see also Lachapelle et al. 2012) and the mechanisms involved. 
Stated preference methods applied by economists (see for example Cai, Cameron and Gerdes 2010; Cole and Brännlund 2009; Dietz and Atkinson 2010) offer the possibility to assess policy acceptability with regard to policy attributes, context and cost and allow for computing the exact financial value of policy attributes (such as effectiveness, instrument characteristics, cost distribution, revenue use or policy label) and thus allow a comparison between contexts and attributes (see Alló and Loureiro 2014; Nemet and Johnson 2010; for review Zvěřinová et al. 2014). A multidisciplinary approach with attention to context-specific factors is recommended for future inquiries in policy acceptability and support.

The analysis confirmed several factors previously identified as influencing acceptability of environmental policies in general in the Czech Republic, namely environmental concern, preference for state regulation, and age. However, postmaterialist value orientation has no statistically significant effect in the Czech data. This is consistent with results of Hadler and Wohlkönig (2012) for public environmental behaviour (such as petitioning) and for private environmental behaviour (such as recycling).

Regarding the role of trust, the results open several questions for future research. First, general social trust appears to have no effect on general policy acceptability, while scepticism towards politicians' motivations is positively related to acceptability. Effects of different measures of trust, both general social and institutional and toward policy-makers should be assessed as more complex relationships may be uncovered. Specifically, phrasing targeted at the expectation that others would act responsibly or comply with the policy seems like a good start (see for example Harring and Jagers 2013).

In the context of the Czech Republic and its history of rather controversial implementation of environmental policies, the high levels of positive attitudes towards presented policies, although presumably positively biased, hold some hope for overall positive perceptions of the endeavour to save the environment with the help of policy instruments, although it is clear that the Czech public is not willing to sacrifice much to help the cause.

\section{References}

ADAMAN, Fikret et al. 2011. "What Determines Urban Households' Willingness to Pay for $\mathrm{CO}_{2}$ Emission Reductions in Turkey: A Contingent Valuation Survey.” Energy Policy 39(2): 689-698.

ALLISON, Paul D. 2002. Missing Data. Thousand Oaks: SAGE.

ALLÓ, Maria and Maria L. LOUREIRO. 2014. "The Role of Social Norms on Preferences towards Climate Change Policies: A Meta-Analysis." Energy Policy 73: 563-574.

ATTARI, Shahzeen Z. et al. 2009. "Preferences for Change: Do Individuals Prefer Voluntary Actions, Soft Regulations, or Hard Regulations to Decrease Fossil Fuel Consumption?" Ecological Economics 68(6): 1701-1710.

BATEL, Susana, Patrick DEVINE-WRIGHT and Torvald TANGELAND. 2013. "Social Acceptance of Low Carbon Energy and Associated Infrastructures: A Critical Discussion.” Energy Policy 58: 1-5.

BORD, Richard J., Robert E. O'CONNOR and Ann FISHER. 2000. "In What Sense Does the Public Need to Understand Global Climate Change?” Public Understanding of Science 3(9): 205-218.

BOSTROM, Ann et al. 2012. "Causal Thinking and Support for Climate Change Policies: International Survey Findings." Global Environmental Change 22(1): 210-222. 
CAI, Beilei, Trudy Ann CAMERON and Geoffrey R. GERDES. 2010. "Distributional Preferences and the Incidence of Costs and Benefits in Climate Change Policy." Environmental and Resource Economics 46(4): 429-458.

COLE, Scott and Runar BRÄNNLUND. 2009. Climate Policy Measures: What Do People Prefer?. Umeå University, Department of Economics. Retrieved December 11, 2013 (http://www.usbe.umu. se/digitalAssets/7/7737_ues767.pdf).

COOLS, Mario et al. 2011. "The Socio-Cognitive Links between Road Pricing Acceptability and Changes in Travel-Behavior." Transportation Research Part A: Policy and Practice 45(8): 779-788.

DIETZ, Simon and Giles ATKINSON. 2010. "The Equity-Efficiency Trade-off in Environmental Policy: Evidence from Stated Preferences." Land Economics 86(3): 423-443.

DIETZ, Thomas, Amy DAN and Rachael SHWOM. 2007. "Support for Climate Change Policy: Social Psychological and Social Structural Influences.” Rural Sociology 72(2): 185-214.

DRESNER, Simon, Louise DUNNE, Peter CLINCH and Christiane BEUERMANN. 2006. "Social and Political Responses to Ecological Tax Reform in Europe: An Introduction to the Special Issue." Energy Policy 34(8): 895-904.

DRESNER, Simon, Tim JACKSON and Nigel GILBERT. 2006. "History and Social Responses to Environmental Tax Reform in the United Kingdom.” Energy Policy 34(8): 930-939.

DREYER, Stacia J. and Iain WALKER. 2013. "Acceptance and Support of the Australian Carbon Policy.” Social Justice Research 26(3): 343-362.

ERIKSSON, Louise, Jörgen GARVILL and Annika M. NORDLUND. 2006. "Acceptability of Travel Demand Management Measures: The Importance of Problem Awareness, Personal Norm, Freedom, and Fairness." Journal of Environmental Psychology 26(1): 15-26.

EUROPEAN COMMISSION. 2014. A Policy Framework for Climate and Energy in the Period from 2020 to 2030.

FIELD, Andy. 2013. Discovering Statistics Using IBM SPSS Statistics. London: SAGE.

FRANZEN, Axel and Reto MEYER. 2010. "Environmental Attitudes in Cross-National Perspective: A Multilevel Analysis of the ISSP 1993 and 2000.” European Sociological Review 26(2): 219-234.

FRANZEN, Axel and Dominikus VOGL. 2013. "Two Decades of Measuring Environmental Attitudes: A Comparative Analysis of 33 Countries." Global Environmental Change 23(5): 1001-1008.

FUJII, Satoshi, Tommy GÄRLING, Cecilia JAKOBSSON and Rong-Chang JOU. 2004. "A Cross-Country Study of Fairness and Infringement on Freedom as Determinants of Car Owners' Acceptance of Road Pricing." Transportation 31(3): 285-295.

FÜRST, Elmar Wilhelm M. and Maria DIEPLINGER. 2013. "The Acceptability of Road Pricing in Vienna: The Preference Patterns of Car Drivers." Transportation 41(4): 765-784.

GELISSEN, J. 2007. "Explaining Popular Support for Environmental Protection: A Multilevel Analysis of 50 Nations." Environment and Behavior 39(3): 392-415.

GRAHAM, John W. 2009. "Missing Data Analysis: Making It Work in the Real World." Annual Review of Psychology 60(1): 549-576.

DE GROOT, Judith I. M. and Geertje SCHUITEMA. 2012. "How to Make the Unpopular Popular? Policy Characteristics, Social Norms and the Acceptability of Environmental Policies." Environmental Science \& Policy 19-20: 100-107.

HADLER, Markus and Patrick WOHLKÖNIG. 2012. "Environmental Behaviours in the Czech Republic, Austria and Germany between 1993 and 2010: Macro-Level Trends and Individual-Level Determinants Compared." Czech Sociological Review 48(3): 467-492.

HALLER, Max and Markus HADLER. 2008. "Dispositions to Act in Favor of the Environment: Fatalism and Readiness to Make Sacrifices in a Cross-National Perspective." Sociological Forum 23(2): 281-311. 
HAMMAR, Henrik and Sverker C. JAGERS. 2006. "Can Trust in Politicians Explain Individuals' Support for Climate Policy? The Case of $\mathrm{CO}_{2}$ Tax." Climate Policy 5(6): 613-625.

HARRING, Niklas. 2013. "Understanding the Effects of Corruption and Political Trust on Willingness to Make Economic Sacrifices for Environmental Protection in a Cross-National Perspective." Social Science Quarterly 94(3): 660-671.

HARRING, Niklas and Sverker JAGERS. 2013. "Should We Trust in Values? Explaining Public Support for Pro-Environmental Taxes.” Sustainability 5(1): 210-227.

INGLEHART, Ronald. 1977. The Silent Revolution: Changing Values and Political Styles among Western Publics. Princeton: Princeton University Press.

INGLEHART, Ronald. 1995. "Public Support for Environmental Protection: Objective Problems and Subjective Values in 43 Societies." PS: Political Science and Politics 28(1): 57-72.

IVANOVA, Galina and Bruce TRANTER. 2008. "Paying for Environmental Protection in a CrossNational Perspective.” Australian Journal of Political Science 43(2): 169-188.

JAENSIRISAK, Sittha, Mark WARDMAN and Anthony D. MAY. 2005. "Explaining Variations in Public Acceptability of Road Pricing Schemes." Journal of Transport Economics and Policy 39(2): $127-154$.

JAGERS, Sverker C., Åsa LÖFGREN and Johannes STRIPPLE. 2010. "Attitudes to Personal Carbon Allowances: Political Trust, Fairness and Ideology.” Climate Policy 10(4): 410-431.

JIN, Myung H. and Avrum J. SHRIAR. 2013. "Linking Environmental Citizenship and Civic Engagement to Public Trust and Environmental Sacrifice in the Asian Context." Environmental Policy and Governance 23(4): 259-273.

KALLBEKKEN, Steffen and Håkon SÆLEN. 2011. "Public Acceptance for Environmental Taxes: SelfInterest, Environmental and Distributional Concerns.” Energy Policy 39(5): 2966-2973.

KIM, Junghwa, Jan-Dirk SCHMÖCKER, Satoshi FUJII and Robert B. NOLAND. 2013. "Attitudes towards Road Pricing and Environmental Taxation among US and UK Students." Transportation Research Part A: Policy and Practice 48: 50-62.

LACHAPELLE, Erick, Christopher P. BORICK and Barry RABE. 2012. "Public Attitudes toward Climate Science and Climate Policy in Federal Systems: Canada and the United States Compared." Review of Policy Research 29(3): 334-357.

LEISEROWITZ, Anthony. 2006. "Climate Change Risk Perception and Policy Preferences: The Role of Affect, Imagery, and Values.” Climatic Change 77(1-2): 45-72.

LEITE, Walter and Natasha S. BERETVAS. 2010. "The Performance of Multiple Imputation for LikertType Items with Missing Data.” Journal of Modern Applied Statistical Methods 9(1): 64-74.

LOCKWOOD, Matthew. 2011. "Does the Framing of Climate Policies Make a Difference to Public Support? Evidence from UK Marginal Constituencies.” Climate Policy 11(4): 1097-1112.

LÖFGREN, Åsa and Katarina NORDBLOM. 2009. "Puzzling Tax Attitudes and Labels." Applied Economics Letters 16(18): 1809-1812.

LUBELL, Mark and Arnold VEDLITZ. 2006. "Collective Action, Environmental Activism, and Air Quality Policy.” Political Research Quarterly 59(1): 149-160.

MÁCA, Vojtěch. 2013. CECILIA2050 Country Report: Czech Republic. Prague: Charles University Environment Center. Retrieved April 9, 2015 (http://cecilia2050.eu/publications/).

MARQUART-PYATT, Sandra T. 2012a. "Contextual Influences on Environmental Concerns CrossNationally: A Multilevel Investigation.” Social Science Research 41(5): 1085-1099.

MARQUART-PYATT, Sandra T. 2012b. "Environmental Concerns in Cross-National Context: How Do Mass Publics in Central and Eastern Europe Compare with Other Regions of the World?" Sociologický časopis/Czech Sociological Review 48(3): 441-466.

McCRIGHT, Aaron M. 2008. "Social Bases of Climate Change Knowledge, Concern, and Policy Support in the U. S. General Public.” Hofstra Law Review 37(4): 1017-1047. 
NEMET, Gregory and Evan JOHNSON. 2010. Willingness to Pay for Climate Policy: A Review of Estimates. La Follette School Working Paper No. 2010-011. Retrieved April 4, 2013 (http:// papers.ssrn.com/abstract=1626931).

OLOFSSON, Anna and Susanna OHMAN. 2006. "General Beliefs and Environmental Concern: Transatlantic Comparisons.” Environment and Behavior 38(6): 768-790.

POORTINGA, Wouter, Alexa SPENCE, Christina DEMSKI and Nick F. PIDGEON. 2012. "IndividualMotivational Factors in the Acceptability of Demand-Side and Supply-Side Measures to Reduce Carbon Emissions." Energy Policy 48: 812-819.

PRIDMORE, Alison and Apollonia MIOLA. 2011. Public Acceptability of Sustainable Transport Measures: A Review of the Literature. OECD Publishing. Retrieved April 4, 2013 (http://econpapers. repec.org/paper/oecitfaab/2011_2f20-en.htm).

ŘEHÁKOVÁ, Blanka. 2001. "Determinanty vztahu k ochraně životního prostředí.” Sociologický časopis 37(4): 479-498.

RHODES, Ekaterina and Mark JACCARD. 2013. "A Tale of Two Climate Policies: Political Economy of British Columbia's Carbon Tax and Clean Electricity Standard.” Canadian Public Policy 39(2): 37-51.

ROTH, Philip L. 1994. "Missing Data: A Conceptual Review for Applied Psychologists." Personnel Psychology 47(3): 537-560.

SÆLEN, Håkon and Steffen KALLBEKKEN. 2011. "A Choice Experiment on Fuel Taxation and Earmarking in Norway.” Ecological Economics 70(11): 2181-2190.

SCHADE, Jens and Bernhard SCHLAG. 2000. Acceptability of Urban Transport Pricing. Government Institute for Economic Research Finland (VATT). Retrieved April 3, 2013 (http://ideas.repec.org/p/ fer/resrep/72.html).

SCHADE, Jens and Bernhard SCHLAG. 2003. “Acceptability of Urban Transport Pricing Strategies." Transportation Research Part F: Traffic Psychology and Behaviour 6(1): 45-61.

SCHAFER, Joseph L. and John W. GRAHAM. 2002. "Missing Data: Our View of the State of the Art." Psychological Methods 7(2): 147-177.

SCHMÖCKER, Jan-Dirk, Pierre PETTERSSON and Satoshi FUJII. 2012. "Comparative Analysis of Proximal and Distal Determinants for the Acceptance of Coercive Charging Policies in the UK and Japan.” International Journal of Sustainable Transportation 6(3): 156-173.

SCHUITEMA, Geertje, Linda STEG and Monique KRUINING. 2011. "When Are Transport Pricing Policies Fair and Acceptable?" Social Justice Research 24(1): 66-84.

SHWOM, Rachael, David BIDWELL, Amy DAN and Thomas DIETZ. 2010. "Understanding U.S. Public Support for Domestic Climate Change Policies.” Global Environmental Change 20(3): 472-482.

SINHARAY, Sandip, Hal S. STERN and Daniel RUSSELL. 2001. "The Use of Multiple Imputation for the Analysis of Missing Data." Psychological Methods 6(4): 317-329.

SOUKUP, Petr. 2001. ISSP - Životni prostředi. Praha: Sociologický ústav AV ČR.

SOUKUP, Petr and Natálie JANDOVÁ. 2001. "Češi a životní prostředí (na okraj jednoho výzkumu)." Pp. 222-33 in Environmentálni ekonomie, politika a vnějš́ vztahy České republiky, edited by Petr ŠAUER. Praha: Nakladatelství a vydavatelství litomyšlského semináře.

STEG, Linda, Lieke DREIJERINK and Wokje ABRAHAMSE. 2005. "Factors Influencing the Acceptability of Energy Policies: A Test of VBN Theory." Journal of Environmental Psychology 25(4): 415-425.

STEG, Linda, Lieke DREIJERINK and Wokje ABRAHAMSE. 2006. "Why Are Energy Policies Acceptable and Effective?" Environment and Behavior 38(1): 92-111.

STEG, Linda, Judith I. M. DE GROOT, Lieke DREIJERINK, Wokje ABRAHAMSE and Frans SIERO. 2011. "General Antecedents of Personal Norms, Policy Acceptability, and Intentions: The Role of Values, Worldviews, and Environmental Concern." Society \& Natural Resources 24(4): 349-367. 
STEG, Linda and Geertje SCHUITEMA. 2007. "Behavioral Responses to Transport Pricing: A Theoretical Analysis.” Pp. 347-66 in Threats from Car Traffic to the Quality of Urban Life: Problems, Causes, and Solutions, edited by Tommy GÄRLING and Linda STEG. Oxford: Elsevier.

STEG, Linda and Charles VLEK. 2009. "Encouraging pro-Environmental Behaviour: An Integrative Review and Research Agenda." Journal of Environmental Psychology 29(3): 309-317.

STERN, Paul C. 2000. "Toward a Coherent Theory of Environmentally Significant Behavior." Journal of Social Issues 56(3): 407-424.

STERN, Paul C., Thomas DIETZ, Troy ABEL, Gregory A. GUAGNANO and Linda KALOF. 1999. "A Value-Belief-Norm Theory of Support for Social Movements: The Case of Environmentalism." Human Ecology Review 6(2): 81-97.

ZAHRAN, Sammy, Samuel D. BRODY, Himanshu GROVER and Arnold VEDLITZ. 2006. "Climate Change Vulnerability and Policy Support." Society \& Natural Resources 19(9): 771-789.

ZVĚŘINOVÁ, Iva, Milan ŠČASNÝ and Eva KYSELÁ. 2014. What Influences Public Acceptance of the Current Policies to Reduce GHG Emissions?. Prague: Charles University, Environment Center. Retrieved April 9, 2015 (http://cecilia2050.eu/publications/239).

\section{Author}

Eva Kyselá studies and works at the Department of Sociology at Faculty of Arts, Charles University in Prague and also collaborates with the Charles University Environment Center. She specializes in environmental sociology with special consideration to issues of perception and knowledge (e.g. risk perception, legitimacy, perceived effectiveness and fairness of policies). In her dissertation thesis she focuses on social acceptability of different environmental policies and policy instruments.

Contact: eva.kysela@ff.cuni.cz 


\section{Appendix}

Table 3: Univariate statistics and question wording - independent variables (original weighted data)

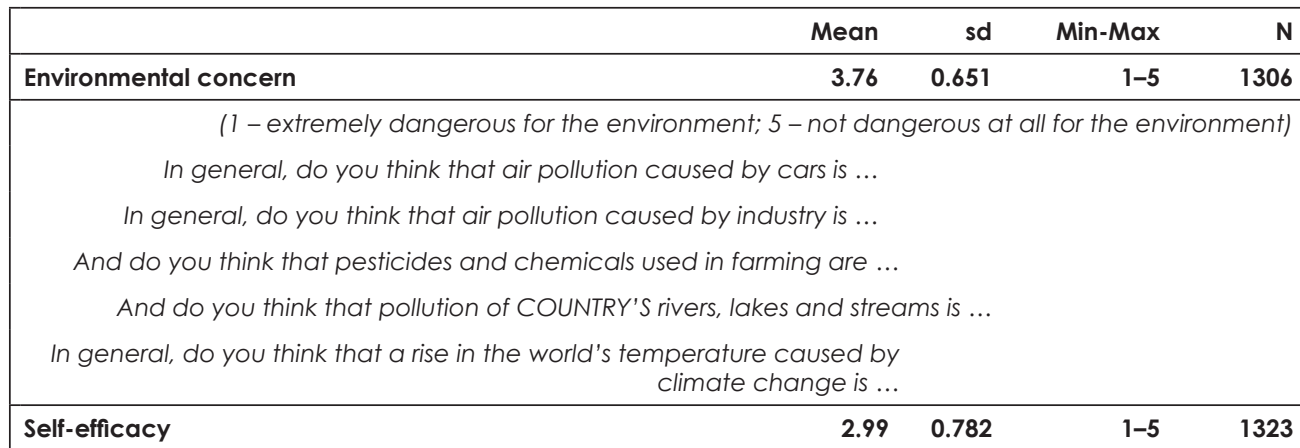

Q: How much do you agree or disagree with each of these statements?

(1 - Agree strongly; 5 - Disagree strongly)

It is just too difficult for someone like me to do much about the environment

There are more important things to do in life than protect the environment

There is no point in doing what I can for the environment unless others do the same

Many of the claims about environmental threats are exaggerated

I find it hard to know whether the way I live is helpful or harmful to the environment

$\begin{array}{llll}\text { General social trust } & 2.68 & 0.980 & 1-5\end{array}$

1417

Generally speaking, would you say that most people can be trusted, or that you can't be too careful in dealing with people?

Please tick one box to show what you think, where 1 means you can't be too careful and 5 means most people can be trusted.

Generally speaking, do you think that most people would try to take advantage of you if they got the chance, or would they try to be fair?

Please tick one box to show what you think, where 1 means most people would try to take advantage of you and 5 means that most people would try to be fair.

Postmaterialist value orientation

\begin{tabular}{|c|c|c|c|}
\hline materialist & mixed & postmaterialist & \\
\hline $\begin{array}{r}35.3 \% \\
(504)\end{array}$ & $\begin{array}{r}53.5 \% \\
(764)\end{array}$ & $\begin{array}{r}6.8 \% \\
(97)\end{array}$ & $\begin{array}{r}4.3 \% \\
(62)\end{array}$ \\
\hline
\end{tabular}

Q: Looking at the list below, please tick a box next to the one thing you think should be [COUNTRY'S] highest priority, the most important thing it should do.

Q: And which one do you think should be [COUNTRY'S] next highest priority, the second most important thing it should do?

\begin{tabular}{|c|c|c|c|c|c|}
\hline \multicolumn{2}{|l|}{ 1: Maintain order in the nation } & \multicolumn{4}{|c|}{ 2: Give people more say in government decisions } \\
\hline \multicolumn{2}{|l|}{ 3: Fight rising prices } & \multicolumn{4}{|c|}{ 4: Protect freedom of speech } \\
\hline \multicolumn{6}{|l|}{ Trust towards politicians } \\
\hline $\begin{array}{r}\text { Agree } \\
\text { strongly }\end{array}$ & Agree & $\begin{array}{r}\text { Neither } \\
\text { agree nor } \\
\text { disagree }\end{array}$ & Disagree & $\begin{array}{r}\text { Disagree } \\
\text { strongly }\end{array}$ & $\begin{array}{l}\text { Don't } \\
\text { know }\end{array}$ \\
\hline $\begin{array}{r}34 \% \\
(485)\end{array}$ & $\begin{array}{r}34.5 \% \\
(493)\end{array}$ & $\begin{array}{r}20.6 \% \\
(295)\end{array}$ & $\begin{array}{r}7 \% \\
(100)\end{array}$ & $\begin{array}{r}2.4 \% \\
(35)\end{array}$ & $\begin{array}{r}1.3 \% \\
(19)\end{array}$ \\
\hline
\end{tabular}




\begin{tabular}{|c|c|c|c|}
\hline \multicolumn{4}{|c|}{ Q: Most politicians are in politics only for what they can get out of it personally } \\
\hline \multicolumn{4}{|l|}{ Preferences for the role of the state } \\
\hline $\begin{array}{r}\text { both individual } \\
\text { action }\end{array}$ & & both state regulation & Don't know \\
\hline $\begin{array}{l}7.8 \% \\
(111)\end{array}$ & $\begin{array}{r}21.8 \% \\
(311)\end{array}$ & $\begin{array}{r}56.5 \% \\
(807)\end{array}$ & $\begin{array}{r}13.9 \% \\
(198)\end{array}$ \\
\hline \multicolumn{4}{|c|}{$\begin{array}{r}\text { Government should let ordinary people/businesses decide for themselves how to protect the } \\
\text { environment, even if it means they don't always do the right thing }\end{array}$} \\
\hline $\begin{array}{r}\text { Government should pass laws to mak } \\
\text { even if it int }\end{array}$ & $\begin{array}{l}\text { ordina } \\
\text { rferes } w\end{array}$ & $\begin{array}{l}\text { usinesses protect the el } \\
\text { s rights to make their ow }\end{array}$ & \\
\hline
\end{tabular}

Table 4: Kendall's tau-b correlation matrix for variables included in the model (original weighted data; $\mathrm{N}=1427$ )

\begin{tabular}{|c|c|c|c|c|c|c|c|c|c|c|}
\hline & W. sacr. & $\begin{array}{l}\text { Social } \\
\text { trust }\end{array}$ & $\begin{array}{c}\text { Envi. } \\
\text { concern }\end{array}$ & \begin{tabular}{|c|} 
Self- \\
efficacy
\end{tabular} & Age & $\begin{array}{l}\text { Social } \\
\text { status }\end{array}$ & $\begin{array}{l}\text { Political } \\
\text { orient. }\end{array}$ & Pol. trust & $\begin{array}{l}\text { Role of } \\
\text { state }\end{array}$ & Postmat \\
\hline $\begin{array}{l}\text { Policy } \\
\text { acceptability }\end{array}$ & $\begin{array}{c}0.010 \\
N=1390\end{array}$ & $\begin{array}{l}-0.056^{\prime \prime} \\
N=1416\end{array}$ & $\begin{array}{c}0.255^{* *} \\
N=1330\end{array}$ & \begin{tabular}{|c|}
$0.104^{* *}$ \\
$N=1350$
\end{tabular} & $\begin{array}{l}-0.092^{* *} \\
N=1418\end{array}$ & $\begin{array}{l}-0.001 \\
N=1389\end{array}$ & $\begin{array}{l}-0.002 \\
N=1187\end{array}$ & $\begin{array}{l}-0.116^{* *} \\
N=1415\end{array}$ & $\begin{array}{c}0.160^{* *} \\
N=1250\end{array}$ & $\begin{array}{c}0.025 \\
N=1368\end{array}$ \\
\hline Will. to sacrifice & 1.000 & $\begin{array}{l}0.143^{* *} \\
N=1450\end{array}$ & \begin{tabular}{|c|}
$0.148^{* *}$ \\
$N=1347$
\end{tabular} & \begin{tabular}{|c|}
$0.295^{* *}$ \\
$N=1361$ \\
\end{tabular} & $\begin{array}{l}-0.064 \\
N=1445\end{array}$ & $\begin{array}{c}0.221^{* *} \\
N=1409\end{array}$ & $\begin{array}{c}0.170^{* *} \\
N=1207\end{array}$ & $\begin{array}{l}0.150^{*} \\
N=1444\end{array}$ & $\begin{array}{l}0.117^{* *} \\
N=1260\end{array}$ & $\begin{array}{l}0.189^{* *} \\
N=1396\end{array}$ \\
\hline Social trust & & 1.000 & \begin{tabular}{|l|}
$-0.057^{* *}$ \\
$N=1367$
\end{tabular} & \begin{tabular}{|c|}
$0.086 " *$ \\
$N=1389$ \\
\end{tabular} & $\begin{array}{l}-0.034 \\
N=1480\end{array}$ & $\begin{array}{c}0.052^{*} \\
N=1441\end{array}$ & $\begin{array}{l}0.070^{* \prime} \\
N=1229\end{array}$ & $\begin{array}{l}0.255^{* \prime} \\
N=1476\end{array}$ & $\begin{array}{c}0.043 \\
N=1287\end{array}$ & $\begin{array}{l}0.081^{*+} \\
N=1427\end{array}$ \\
\hline Envi. concern & & & 1.000 & \begin{tabular}{|l|}
$\mathbf{0 . 2 0 7 *}$ \\
$N=1306$ \\
\end{tabular} & $\begin{array}{l}-0.025 \\
N=1368\end{array}$ & $\begin{array}{l}-0,004 \\
N=1335\end{array}$ & $\begin{array}{l}-0.023 \\
N=1136\end{array}$ & $\begin{array}{l}-0.066 " \\
N=1365\end{array}$ & $\begin{array}{c}0.110^{* \prime} \\
N=1215\end{array}$ & $\begin{array}{l}0.067^{* *} \\
N=1323\end{array}$ \\
\hline Self-efficacy & & & & 1.000 & $\begin{array}{l}-0.045^{*} \\
N=1386 \\
\end{array}$ & $\begin{array}{l}0.149^{* *} \\
N=1358\end{array}$ & $\begin{array}{c}0.116^{* \prime} \\
N=1161\end{array}$ & $\begin{array}{c}0.108^{* *} \\
N=1386\end{array}$ & $\begin{array}{c}0.176^{* *} \\
N=1225\end{array}$ & $\begin{array}{c}0.120^{* *} \\
N=1336\end{array}$ \\
\hline Age & & & & & 1.000 & $\begin{array}{l}-0.122^{* *} \\
N=1441\end{array}$ & $\begin{array}{l}-0.224^{*} \\
N=1227\end{array}$ & $\begin{array}{l}-0.043^{*} \\
N=1474\end{array}$ & $\begin{array}{c}0.028 \\
N=1286\end{array}$ & $\begin{array}{l}-0.137^{* *} \\
N=1423\end{array}$ \\
\hline Social status & & & & & & 1.000 & $\begin{array}{c}0.351^{* *} \\
N=1222\end{array}$ & $\begin{array}{l}0.134^{* \prime} \\
N=1437\end{array}$ & $\begin{array}{c}0.031 \\
N=1260\end{array}$ & $\begin{array}{l}0.116^{* *} \\
N=1390\end{array}$ \\
\hline Political orient. & & & & & & & 1.000 & $\begin{array}{c}0.143^{* \prime} \\
N=1228\end{array}$ & $\begin{array}{c}0.026 \\
N=1086\end{array}$ & $\begin{array}{l}0.169^{* *} \\
N=1188\end{array}$ \\
\hline Trust in politicians & & & & & & & & 1.000 & $\begin{array}{c}0.036 \\
N=1283\end{array}$ & $\begin{array}{l}-0.079^{* *} \\
N=1421\end{array}$ \\
\hline
\end{tabular}

